\title{
Virtuel undervisning i gymnasiet
}

Ane Qvortrup, Syddansk Universitet

Rune Hejli Lomholt, Syddansk Universitet

\begin{abstract}
Gymnasieundervisningen under skolenedlukningerne var først og fremmest nødundervisning i forbindelse med en samfundskrise. Men udover at være nødundervisning var den et eksperiment ud i virtuel undervisning. Med dette udgangspunkt undersøger denne artikel gymnasieelevernes oplevelse af den virtuelle undervisning, idet der er særligt fokus på deres oplevelse af faglig mestring og motivation. Empirisk er artiklen baseret på et mixed method-design med kvantitative data baseret på elevbesvarelser af et spørgeskema $(\mathrm{N}=2899)$ indsamlet $\mathrm{i}$ april 2020 og fokusgruppeinterviews med elever $(\mathrm{N}=44)$ indsamlet i april-juni 2020. Artiklen viser, at især den faglige motivation var lav. På baggrund af artiklens analyser udpeges en række temaer, som kan reflekteres i forbindelse med fremtidig virtuel undervisning i gymnasiet.
\end{abstract}

\section{Engelsk abstract}

Upper secondary education during school closures was first and foremost emergency education related to a societal crisis. But in addition to being emergency education, it was an experiment in virtual teaching. With this in mind, this article examines students' experience of virtual teaching, with a particular focus on their experience of academic mastery and motivation. Empirically, the article is based on a mixed method design with quantitative data from questionnaire data from students $(\mathrm{N}=2899)$ collected in April 2020 and focus group interviews with students $(\mathrm{N}=44)$ collected in April-June 2020. The article shows that especially the academic motivation was low. On the basis of the article's analyses, a number of themes are identified that can be reflected on in relation to future virtual teaching in upper secondary schools. 


\section{Introduktion}

2020 var et anderledes og mærkeligt skoleår for de danske gymnasieelever. Gymnasierne blev lukket ned 11. marts grundet risikoen for spredning af COVID-19, og først efter lidt mere end en måneds undervisning på distance kunne de ældste elever, 3.g- og 2.hf-eleverne, d. 15. april vende tilbage. Fra den 27. maj 2020 - efter mere end to måneders hjemmeundervisning - kunne også 1.g'erne og 2.g'erne igen modtage undervisning på skolen. Sommeren og efteråret var præget af stor usikkerhed og en række lokale skolenedlukninger for kortere og længere perioder grundet svingende infektionstal. I slutningen af året måtte alle skolerne lukke ned igen, og først i maj 2021 kunne en anden genåbning finde sted.

Undervisningen under skolenedlukningerne har først og fremmest været nødundervisning, dvs. undervisning, som ikke har haft de optimale rammer og betingelser for hverken at nå den enkelte elev eller at opfylde de faglige læreplansmål (BEK nr 242 af 19/03/2020 og LOV nr 241 af 19/03/2020). Udover at være nødundervisning kan undervisningen imidlertid også karakteriseres som et eksperiment ud i virtuel undervisning. Selvom mange års erfaring med og forskning i virtuel undervisning går forud for COVID-19-skolenedlukningerne, kendetegnede eksperimentet sig i denne periode ved have den fulde population af danske gymnasie-elever og -lærere som deltagere og ved at spænde over en længere periode, end det ellers har været tilfældet (jf. fx Mutch, 2020). Samtlige lærere og elever i de danske gymnasier har grundet udefrakommende omstændigheder - ikke pga. egne særlige interesser eller forudsætninger, en forskers nysgerrighed eller rektors beslutning - været tvunget ud i en eksperimenterende tilgang. Som en lærer udtrykker det i et interview gennemført i juni 2020:

"Man blev givet meget frihed, og der blev også vist meget tillid ift. måden at håndtere det på, fordi mange stod jo også med små børn, der skulle passes og sådan noget [...]. Jeg har oplevet det som en metodisk frihed til at gøre det, som der giver bedst mening [...] og det er jeg hele tiden blevet klogere på, hvad det er, der fungerer, og hvad der ikke fungerer"

Ifølge læreren var friheden under nedlukningen begrundet i omstændighederne, men den har givet mulighed for at være metodisk nysgerrig, undersøgende og udviklende. Selvom der umuligt kan generaliseres direkte fra COVID-19-situationen til undervisning under almindelige rammer og betingelser, har der i situationen været udviklet erfaringer med brugen af virtuel undervisning, som kan udvide og forstyrre vores hidtil opnåede erfaringer med og viden om virtuel undervisning. Dette perspektiv er væsentligt i gymnasiet, hvor 'Bekendtgørelse om de gymnasiale uddannelser' åbner op for, at det enkelte gymnasium kan vælge at anvende dele af undervisningstiden til undervisning, som foregår virtuelt (Aftale 2016).

Denne artikel sætter kvantitativt fokus på elevernes faglige mestringsoplevelser og motivation ifm. den virtuelle undervisning, suppleret med et kvalitativt bredt blik på elevernes oplevelse af undervisningen. Som det begrundes i afsnittet nedenfor, udpeges faglige mestringsoplevelser og motivation som væsentlige opmærksomhedspunkter ifm. et skift til virtuel undervisning.

Forskningsspørgsmålet lyder:

* Hvad karakteriserer elevernes faglige mestringsoplevelse og motivation i forbindelse med den virtuelle undervisning under COVID-19, og hvilke temaer træder på baggrund heraf frem som relevante at reflektere over i forbindelse med virtuel undervisning i fremtiden?

Empirisk er artiklen baseret på et mixed method-design med kvantitative spørgeskemadata med elever $(\mathrm{N}=2942)$ indsamlet $\mathrm{i}$ april 2020 og 20 fokusgruppeinterviews med elever $(\mathrm{N}=44)$ indsamlet i april-juni 2020. 


\section{Faglig mestring og motivation}

Allerede i den første fase af COVID-19 var der nationalt mange bekymringer for og bud på, hvilke konsekvenser skolenedlukningerne ville have for elevernes trivsel og læring, og denne bekymring har siden vist sig tydeligt i diskurser om fagligt efterslæb, den tabte årgang, etc. (Berlingske, 2021; TV Midtvest 2021). Bekymringer virker velbegrundede i den internationale litteratur, som er systematisk beskrevet i Qvortrup (2021). Brooks, Webster, Smith, Woodland, Wessely, Greenberg og Rubin (2020) udarbejder et review over konsekvenserne af tidligere lignende karantæner og konkluderer, at 'Most reviewed studies reported negative psychological effects' (p. 912). På baggrund af interviews med statslige repræsentanter konkluderer Gill, Goyal, Hartog, Hotchkiss og DeLisle (2020) tilsvarende, at 'many respondents were concerned that social isolation, excessive screen time, and irregular schedules would present a major challenge for pupils in readjusting to school in the fall' (p. 19). Hvis vi ser udover COVID-19, er det velkendt fra tidligere midlertidige skolenedlukninger som følge af pandemier (jf. H1N1 og HIV/AIDS), samfundskriser (jf. 9/11) eller farer forårsaget af fx jordskælv, at sådanne situationer udgør en risiko for studerendes trivsel og kan påvirke deres faglige udvikling, både i et kortsigtet og et langsigtet perspektiv (Qvortrup 2021). De trivselsmæssige og faglige konsekvenser kan undersøges med fokus på elevernes oplevelse af faglig mestring og motivation, som udpeges som væsentlige opmærksomhedspunkter ifm. et skift til virtuel undervisning (Tladi 2017, Al Fadda 2019, Chung 2015, Tosuncuoglu 2019, Wang, Peng, Huang, Hou, \& Wang 2008, Madonna \& Philpot 2013, Peck, Stefaniak \& Shah 2018, Yang \& Park 2012, Berger-Tikochinski, Zion \& Spektor-Levy 2016, Gulten, Yaman, Deringol \& Ozsari 2011, Larbi-Apau, Oti-Boadi \& Tetteh 2018). I overensstemmelse med de refererede studier forstår vi faglig mestring som elevernes oplevelse af at kunne udføre den adfærd, der er nødvendig for at nå bestemte præstationsresultater i konkrete kontekster eller ved konkrete opgaver (Bandura 1977; Bandura \& Wood 1989). Faglig motivation forstås vi med reference til Hochschild (1990) og Qvortrup (2021) som glæden ved at deltage i undervisning og ved at lære noget. Når faglig mestring og motivation udpeges som væsentlige opmærksomhedspunkter skyldes det, at oplevelsen af faglig mestring og motivation har afgørende betydning for at fastholde eleverne i den virtuelle undervisning, som stiller øgede krav om selvregulering og vedholdenhed (Al Fadda 2019; Chung 2015). Samtidig udfordrer skiftet til virtuel undervisning ofte netop oplevet faglig mestring og motivation, fordi undervisningen er ukendt og anderledes end normalt, og fordi eleverne ikke nødvendigvis kan imødekomme de digitale krav og e-læringskompetencer, der kræves for at deltage i virtuel undervisning (Larbi-Apau, Oti-Boadi og Tetteh 2018).

\section{Metode}

\section{Design og respondenter}

Analyserne i denne artikel trækker for det første på spørgeskemadata indsamlet på 11 forskellige gymnasier (stx, hhx, htx og hf), en indsamling som blev gennemført i april 2020 som del af forskningsprojektet "Gymnasiet i den historiske Corona-tid - et elevperspektiv" (Qvortrup 2020a). Forskningsprojektet benyttede et stikprøvedesign baseret på frivillig deltagelse af gymnasier, der udvalgte hele klasser til deltagelse. For det andet trækker analyserne på fokusgruppeinterviews med elever gennemført i april-juni 2020 som led i en større longitudinal undersøgelse af elevernes udvikling gennem gymnasietiden (Qvortrup 2020b). I både spørgeskema og interviews blev eleverne spurgt til deres hverdag under skolenedlukningerne, deres oplevelse af den virtuelle undervisning, til brugen af undervisningstyper samt til deres faglige motivation og oplevelse af faglige mestring.

Den kvantitative stikprøve bestod af svar fra 2942 gymnasieelever. Elevkarakteristika for den kvantitative stikprøve er sammenfattet i tabel 1: 
Tabel 1. Elevkarakteristika i den kvantitative stikprøve

\begin{tabular}{lrr}
\hline Karakteristika & $\mathbf{N}$ & $\mathbf{\%}$ \\
\hline Køn & & \\
Dreng/mand & 1233 & $42 \%$ \\
Pige/kvinde & 1709 & $58 \%$ \\
& & \\
Gymnasial uddannelsestype & & \\
HF & 152 & $5 \%$ \\
HHX & 1205 & $41 \%$ \\
HTX & 635 & $22 \%$ \\
STX & 950 & $32 \%$ \\
& & \\
Trin & & \\
1.g & 1038 & $35 \%$ \\
2.9 & 1016 & $35 \%$ \\
3.9 & 888 & $30 \%$ \\
\hline$N=2942$ & & \\
\hline
\end{tabular}

Spørgeskemaet blev udsendt til den samlede elevgruppe på de deltagende gymnasier via gymnasiernes online kommunikationsplatforme. Alle elever svarede anonymt på undersøgelsen ved selv at oprette sig som respondent via et link. I spørgeskemaet blev eleverne præsenteret for en række lukkede spørgsmål og udsagn angående de undersøgte temaer. De blev bedt om at give deres vurdering af disse oplevelser på en traditionel Likert responsskala med fem punkter.

Den kvalitative stikprøve bestod af i alt 20 fokusgruppeinterview $(\mathrm{N}=44)$ med 2-4 elever fra 11 forskellige gymnasier fra hele landet. Fokusgruppeinterviewene blev udført ved, at hvert af de deltagende gymnasier blev bedt om at udvælge 2-3 elever, der samlet var repræsentative for elevdemografien på skolen. I fokusgruppeinterviewene var der, som foreslået af Halkier (2008), fokus på interaktionen i gruppen og den fælles konstruktion af mening omkring de undersøgte temaer. Interviewene var semistrukturerede, hvor temaerne blev præsenteret, hvorefter der blev givet plads til elevernes interaktion og meningsdannelse, idet intervieweren påtog sig opgaven at styre samtalen, så den ikke endte udenfor de planlagte temaer.

\section{Analysemetoder}

\section{Faktor-analyse}

Konfirmativ faktor-nalyse (KFA) er en statistisk metode, der har til formål at klarlægge strukturen af underliggende faktorer i et datasæt baseret på teoretiske antagelser (Baldwin, 2019; Mehmetoglu \& Jakobsen, 2017). I artiklens analyser brugte vi den til at undersøge, om der var empirisk evidens for vores latente sociale fænomener (faglig mestring og motivation), idet vi forstår de latente sociale fænomener som nogle mere generelle fænomener, der refererer til eller samler flere konkrete aspekter (variable). Faktoranalysen giver mulighed for at vurdere, i hvilken grad hver variabel indikerer den latente faktor, og dermed muliggør den forskellige vægtning af de enkelte variable i efterfølgende analyser.

Tabel 2 viser resultatet af faktor analysen, hvor de enkelte variable af forskningsmæssig interesse er tilskrevet en latent faktor på baggrund af denne analytiske proces. På baggrund af analysen er der udregnet en standardiseret vægtet score for hver af de fire faktorer, som kan bruges i videre analyse. 
Faktor 1 identificeredes som "faglig motivation" på baggrund af to variable, der undersøgte elevernes oplevelse af den virtuelle undervisning som henholdsvis sjov og kedelig. Her havde begge variable nogenlunde samme vægt og indikerede derfor det latente fænomen nogenlunde ligeligt. Faktor 2 identificeredes som "faglig mestring" på baggrund af syv variable, der undersøgte elevernes oplevelse af sværhedsgraden af den virtuelle undervisning og deres oplevelse af at kunne deltage og følge med. Her viste analysen, at det latente fænomen i højere grad indikeredes af de variable, der målte egen oplevelse af at kunne deltage og følge med, end af de variable, der målte oplevelsen af sværhedsgraden; dog kunne alle variable empirisk siges at indikere faglig mestring generelt set. Faktor 3 identificeredes som "tilgængelighed af ressourcepersoner" på baggrund af fire variable, der undersøgte elevernes oplevelse af graden af kontakt med samt muligheden for at modtage faglig hjælp fra lærere og klassekammerater. Her viste analysen, at det latente fænomen i højere grad indikeredes af de variable, der målte elevens oplevelse af muligheden for hjælp fra læreren og kammerater, end af de variable, der målte oplevelsen af kontakt. Faktor 4 identificeredes som "oplevet udbytte af virtuelle undervisningsaktiviteter" på baggrund af fire variable, der målte det oplevede udbytte af undervisningsaktiviteterne lærerpræsentation, fælles diskussion og dialog, gruppearbejde og feedback. Her viste analysen, at det latente fænomen indikeredes omtrent ligeligt af disse variable.

Tabel 2. Summeret statistik for indikator variable og præsentation af KFA-resultater

\begin{tabular}{|c|c|c|c|c|c|c|c|}
\hline & \multicolumn{3}{|c|}{$\begin{array}{l}\text { Summeret } \\
\text { statistik }\end{array}$} & \multicolumn{4}{|c|}{ KFA resultater } \\
\hline Variabel & $\mathbf{N}$ & Gns & SD & Vaegt & SE & Faktor & $\rho^{*}$ \\
\hline Undervisningen er sjov & 2227 & 3,72 & 1,10 & $0,74^{* * *}$ & 0,02 & Faglig motivation & ,79 \\
\hline Undervisningen er kedelig & 2219 & 2,36 & 1,06 & $0,87^{* * *}$ & 0,01 & & \\
\hline $\begin{array}{l}\text { Det er sværere end den undervisning, jeg har i } \\
\text { skolen }\end{array}$ & 2245 & 3,56 & 1,20 & $0,47^{* * *}$ & 0,02 & Faglig mestring & ,81 \\
\hline $\begin{array}{l}\text { Jeg føler mig ekstra afslappet i } \\
\text { undervisningen, når den foregår online }\end{array}$ & 2199 & 3,17 & 1,33 & $0,42^{* * *}$ & 0,02 & & \\
\hline $\begin{array}{l}\text { Jeg har nemt ved at følge med i } \\
\text { undervisningen }\end{array}$ & 2259 & 3,53 & 1,12 & $0,80^{* * *}$ & 0,01 & & \\
\hline $\begin{array}{l}\text { Jeg kan fint koncentrere mig om de } \\
\text { skoleaktiviteter, jeg skal lave i løbet af dagen }\end{array}$ & 2262 & 3,45 & 1,18 & $0,69^{* * *}$ & 0,01 & & \\
\hline $\begin{array}{l}\text { Jeg klarer mig godt i denne form for } \\
\text { undervisning }\end{array}$ & 2085 & 3,26 & 1,15 & $0,75^{* * *}$ & 0,01 & & \\
\hline Jeg forstår de sværeste dele vi arbejder med & 2154 & 3,28 & 1,10 & $0,62^{* * *}$ & 0,02 & & \\
\hline $\begin{array}{l}\text { Jeg forstår de fleste af de ting vi bliver } \\
\text { undervist i }\end{array}$ & 2212 & 3,95 & 0,95 & $0,69^{* * *}$ & 0,01 & & \\
\hline $\begin{array}{l}\text { Jeg har en eller flere gange ugentligt kontakt } \\
\text { med en eller flere af mine lærere }\end{array}$ & 2539 & 3,87 & 1,20 & $0,54^{* * *}$ & 0,02 & $\begin{array}{l}\text { Tilgængelighed af } \\
\text { ressourcepersoner }\end{array}$ &, 76 \\
\hline $\begin{array}{l}\text { Jeg har en eller flere gange ugentligt kontakt } \\
\text { med mine klassekammerater }\end{array}$ & 2580 & 4,43 & 0,97 & $0,53^{* * *}$ & 0,02 & & \\
\hline $\begin{array}{l}\text { Hvis der er dele af opgaverne, jeg ikke forstår, } \\
\text { er det nemt at få hjælp fra en lærer }\end{array}$ & 2566 & 3,31 & 1,20 & $0,71^{* * *}$ & 0,02 & & \\
\hline $\begin{array}{l}\text { Hvis der er dele af opgaverne, jeg ikke forstår, } \\
\text { er det nemt at få hjælp fra en kammerat }\end{array}$ & 2579 & 4,00 & 1,06 & $0,64^{* * *}$ & 0,02 & & \\
\hline Læreren præsenterer fagligt stof online & 2299 & 3,76 & 1,11 & $0,67^{* * *}$ & 0,02 & $\begin{array}{l}\text { Oplevet udbytte af } \\
\text { virtuelle } \\
\text { undervisningsaktiviteter }\end{array}$ & ,72 \\
\hline $\begin{array}{l}\text { Der er fælles diskussion og dialog i klassen } \\
\text { online }\end{array}$ & 2291 & 3,18 & 1,23 & $0,69^{* * *}$ & 0,02 & & \\
\hline $\begin{array}{l}\text { Vi arbejder gruppevis med spørgsmål eller } \\
\text { opgaver online }\end{array}$ & 2308 & 3,97 & 1,01 & $0,61^{* * *}$ & 0,02 & & \\
\hline $\begin{array}{l}\text { Jeg får feedback på mine svar på spørgsmål og } \\
\text { opgaver online }\end{array}$ & 2292 & 3,30 & 1,20 & $0,53^{* * *}$ & 0,02 & & \\
\hline
\end{tabular}

Noter. $\quad$ Signifikansniveau: ${ }^{* * *}=p<$, oo1.

$\mathrm{SD}=$ standardafvigelse (standard deviation). $\mathrm{SE}=$ standardfejl (standard error).

* $\rho=$ Raykov's faktor reliabilitetskoefficient (Raykov, 1997). 


\section{Lineær regressionsanalyse}

Lineær regressionsanalyse blev anvendt til at undersøge sammenhænge mellem henholdsvis faglig motivation og faglig mestring og en række uafhængige variable. Vi estimerede to forskellige modeller på baggrund af forskningsinteressen: 1) gennemsnitlig forventet faglig mestring for elever i forbindelse med den virtuelle undervisning som en funktion af tilgængelighed af ressourcepersoner, faglig motivation, oplevet udbytte af virtuelle undervisningsaktiviteter, gymnasial uddannelsestype og uddannelsestrin, og 2) gennemsnitlig forventet faglig motivation som en funktion af tilgængelighed af ressourcepersoner, faglig mestring, oplevet udbytte af virtuelle undervisningsaktiviteter, oplevelse af variation i undervisningsformerne, gymnasial uddannelsestype og køn.

Da vi opfatter de to modeller som særskilt udpegende temaer til refleksion over den virtuelle undervisning under COVID-19 (og ikke som to modeller, der skulle kompareres ift. effektstørrelser), valgte vi, at de to modeller ikke nødvendigvis skulle indeholde de samme variable. Modellerne er tilpasset ud fra, hvilke variable, der på baggrund af statistisk testning viste sig at bidrage eller ikke bidrage til modellen med signifikant forklaringskraft. Variable, som ikke bidrog til en af modellerne, blev udeladt fra den pågældende regressionsmodel for at beholde fokus på variable med reel statistisk forklaringskraft. Dette betyder, at antallet af variable er forskelligt i de to modeller. Samtidig betyder det, at antallet af respondenter er forskelligt, da ikke alle respondenter har svaret på alle variable. Selvom den overordnede stikprøve er den samme, vil den analytiske stikprøve for hver af modellerne ikke være nøjagtigt den samme. Model 2 indeholder desuden et kvadratterm for variablen "tilgængelighed af ressourcepersoner", da denne udviste et ikke-lineært forhold med faglig motivation.

\section{Content Analysis}

De kvalitative data blev analyseret vha. 'Content Analysis' (CA), som er en induktiv analysetilgang til identificering af temaer i et datasæt, hvor dataene organiseres, håndteres og kodes på en måde, hvor formodninger om datastrukturen, der eksisterer forud for analysen, sættes til side (Zhang \& Wildemuth 2009), og hvor alle svar behandles lige (Denzin \& Lincoln 2000). Alle svar blev læst og kodet systematisk i cykliske processer, hvor genkommende temaer blev identificeret (Berg, 1998). Software-programmet NVivo 12 blev anvendt hertil. Spørgsmålet om troværdighed i analysen bliver tilvejebragt gennem såkaldte 'thick decriptions', dvs. omhyggelige beskrivelser af indholdet i de forskellige kategorier og temaer, der skaber gennemsigtighed og transparens og hjælper læseren med at bedømme såvel soliditeten som overførbarheden af analysens resultater (Ary, et al. 2009).

\section{Resultater}

\section{Faglig mestring}

For at vurdere niveauet af faglig mestring og faglig motivation blandt eleverne i forbindelse med den virtuelle undervisning under COVID-19, konstruerede vi summerede skalaer for disse faktorer. Den summerede skala for faglig mestring følger en meget ens distribution på alle gymnasiale uddannelsestyper, på nær HF der er signifikant anderledes (figur 1). Statistisk analyse viser, at der er signifikante forskelle i gennemsnitlig selvoplevet faglig mestring på de gymnasiale uddannelsestyper. Gennemsnitligt faglig mestring for HF er 3,12 $(n=136, S D=0,96)$ med et modus på 4, for HHX 3,47 ( $n$ $=882, S D=0,82)$ med et modus på 3,83, for HTX 3,41 $(n=524, S D=0,84)$ med et modus på 3,50 og for STX 3,50 $(n=728, S D=0,79)$ med et modus på 3,67. Den generelle oplevelse af faglig mestring i forbindelse med den virtuelle undervisning på gymnasiet under skolenedlukningerne ligger mellem middel og over middel for alle gymnasiale uddannelsestyper i stikprøven og er højest på STX og lavest på HF. Den generelle selvoplevede faglige mestring for hele stikprøven ligger omkring middel med et gennemsnit på $3,45(n=2270, S D=0.83)$ med et modus på 3,67. 


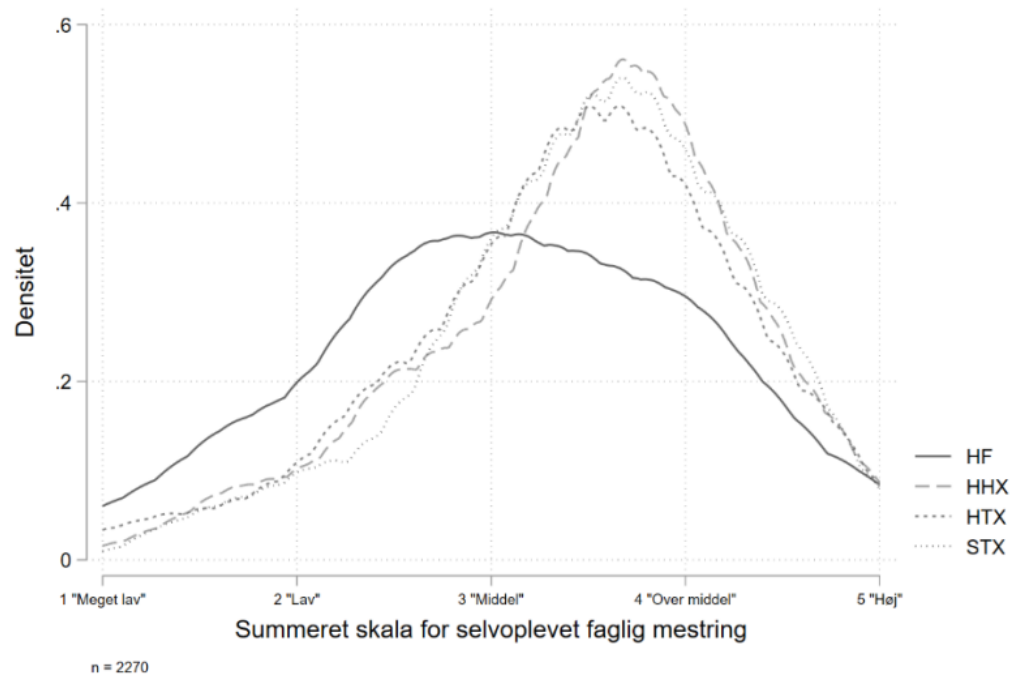

Figur 1. Densitets plot af distributionen for en summeret skala for faglig mestring, fordelt på gymnasiale uddannelsestyper

\section{Faglig motivation}

Den summerede skala for faglig motivation er meget ens i sin distribution på alle gymnasiale uddannelsestyper (figur 2). Gennemsnittet for faglig motivation på HF er 2,31 ( $n=134, S D=1,02)$ med et modus på 1 og 3, på HHX 2,18 $(n=870, S D=0,95)$ med et modus på 1, på HTX 2,48 $(n=516, S D=$ o,99) med et modus på 3 og på STX 2,35 $(n=720, S D=0,97)$ med et modus på 3. Statistisk analyse viser, at der udelukkende er signifikante forskelle mellem STX vs. HHX og HTX vs. HHX. Den selvoplevede faglige motivation blandt gymnasieelever ifm. den virtuelle undervisning under COVID-19 er lav for alle gymnasiale uddannelsestyper og er lavest på HHX og højest på HTX. Den generelle selvoplevede faglige motivation for hele stikprøven er lav med et gennemsnit på $2.31(n=2240, S D=$ o.98) med et modus på 3 .

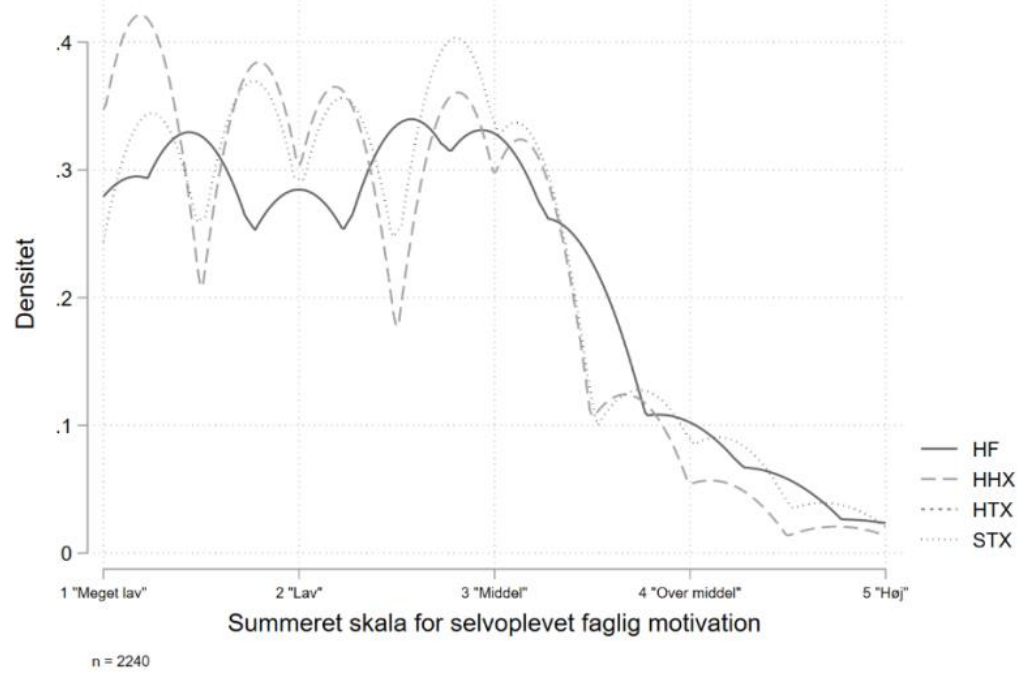

Figur 2. Densitets plot af distributionen for en summeret skala for faglig motivation, fordelt på gymnasiale uddannelsestyper 


\section{Resultater fra regressionsanalysen}

Der blev fundet en signifikant regressionsligning for model 1 med faglig mestring som den afhængige variabel, $F(8,2937)=929,64, p=, 000$, og modellen kan ud fra den korrigerede kvadrat sum $\left(\mathrm{R}^{2}\right)$ gøre rede for $72 \%$ af variansen i selvoplevet faglig mestring. Som det ses i tabel 3, er tilgængelighed af ressourcepersoner samt faglig motivation positivt korreleret med gennemsnitlig forventet faglig mestring i den virtuelle undervisning blandt gymnasieelever i stikprøven. Oplevet udbytte af virtuelle undervisningsaktiviteter, gymnasial uddannelsestype og uddannelsestrin er også signifikant korreleret med faglig mestring, men med meget små effektstørrelser.

Tabel 3. Regressionsmodel 1: Faglig mestring

\begin{tabular}{|c|c|c|c|}
\hline & KOEF & SE & BETA \\
\hline TILGÆNGELIGHED AF RESSOURCERPERSONER a & $0,51^{* * *}$ & ,01 & 0,59 \\
\hline FAGLIG MOTIVATION a & $0,36^{* * *}$ & ,01 & 0,54 \\
\hline UDBYTTE AF VIRTUELLE UNDERVISNINGSAKTIVITETER a & $-0,14^{* * *}$ & ,01 & $-0,19$ \\
\hline \multicolumn{4}{|l|}{ GYMNASIAL UDDANNELSESTYPE } \\
\hline $\mathrm{HF}$ & $-0,09^{* * *}$ & ,01 & $-0,05$ \\
\hline HHX & Ref. & Ref. & Ref. \\
\hline HTX & $-0,07^{* * *}$ & ,01 & $-0,08$ \\
\hline STX & $-0,02$ & ,01 & $-0,02$ \\
\hline \multicolumn{4}{|l|}{ TRIN } \\
\hline $1 . \mathrm{g}$ & Ref. & Ref. & Ref. \\
\hline $2 . g$ & 0,02 & ,01 & 0,02 \\
\hline 3.9 & $0,03^{* *}$ & ,01 & 0,03 \\
\hline Korr. $\mathbf{R}^{2}$ & \multicolumn{3}{|c|}{, 72} \\
\hline $\mathbf{N}$ & \multicolumn{3}{|c|}{2938} \\
\hline
\end{tabular}

Noter. Signifikansniveau: ${ }^{* *}=p<, 01,{ }^{* * *}=p<, 001$
SE $=$ standardfejl (standard error). Beta = standardiserede beta koefficienter. ${ }^{\text {a }}$ Standardiseret vægtet faktor score. Skala; gennemsnit o, varians 1.

Resultaterne fra model 1 indikerer at gymnasielever, som oplever, at lærere og kammerater er tilgængelige som ressourcepersoner, der kan hjælpe fagligt i den virtuelle undervisning, og som føler sig mere fagligt motiverede end den gennemsnitlige elev, også kan forventes at opleve væsentlig bedre faglig mestring.

Der blev fundet en signifikant regressionsligning for model 2 med faglig motivation som den afhængige variabel, $F(12,2386)=375,01, p=, 000$. Modellen kan ud fra den korrigerede kvadratsum $\left(\mathrm{R}^{2}\right)$ gøre rede for $65 \%$ af variansen i selvoplevet faglig motivation. Som det ses i tabel 4 , er oplevelsen af tilgængelige ressourcepersoner overraskende negativt korreleret med faglig motivation. Det er dog vigtigt at lægge mærke til, at oplevelsen af tilgængelige ressourcepersoner har en signifikant ikke-lineær sammenhæng med gennemsnitlig forventet faglig motivation; dvs. når selvoplevet faglig motivation ændrer sig fra at være på gennemsnittet til at være 1 standardafvigelse over gennemsnittet bliver den positiv i sin effekt fremfor at være negativ (jf. koefficienten og det kvadratiske term (\#\#)). Faglig mestring og oplevet udbytte af virtuelle undervisningsaktiviteter er positivt korreleret med faglig motivation. 


\begin{tabular}{lccc} 
& KOEF & SE & BETA \\
\hline TILGÆNGELIGHED AF RESSOURCEPERSONER a & $-0,33^{* * * *}$ & 0,03 & $-0,25$ \\
\#\# Tilgængelighed af ressourcepersoner b & $0,12^{* * *}$ & 0,02 & - \\
FAGLIG MESTRING a & $0,99^{* * *}$ & 0,03 & 0,65 \\
UDBYTTE AF VIRTUELLE UNDERVISNINGSAKTIVITETER a & $0,48^{* * *}$ & 0,02 & 0,43 \\
& & & \\
VARIATION I UNDERVISNINGSFORMERNE c & & & \\
"Slet ikke" & Ref. & Ref. & Ref. \\
"I lav grad" & 0,03 & 0,02 & 0,02 \\
"Hverken/eller" & $0,12^{* * *}$ & 0,03 & 0,07 \\
"I nogen grad" & $0,14^{* *}$ & 0,03 & 0,10 \\
"I høj grad" & $0,15^{* *}$ & 0,04 & 0,08 \\
GYMNASIAL UDDANNELSESTYPE & & & \\
HF & & & \\
HHX & $0,10^{* *}$ & 0,02 & 0,04 \\
HTX & Ref. & Ref. & Ref. \\
STX & $0,10^{*}$ & 0,03 & 0,07 \\
KØN d & 0,01 & 0,03 & 0,01 \\
\hline Korr. R & & & \\
N & 0,03 & 0,02 & 0,02 \\
\hline
\end{tabular}

Noter. Signifikansniveau: ${ }^{*}=p<, 05,{ }^{* *}=p<, 01,{ }^{* * *}=p<, 001$

$\mathrm{SE}=$ standardfejl (standard error). Beta $=$ (standardiserede beta koefficienter). ${ }^{\text {a }}$ Standardiseret vægtet faktor score. Skala; gennemsnit o, varians $1 .{ }^{b}$ Kvadratterm for ikke-lineær sammenhæng. ${ }^{c}$ Enkeltvariabel der viste sig at have forklaringskraft. ${ }^{\mathrm{d}}$ Koefficienten viser forventet faglig mestring for piger/kvinder; drenge/mænd er referencekategorien.

Resultaterne fra model 2 indikerer, at gymnasielever med bedre oplevet faglig mestring kan forventes også at være en hel del mere fagligt motiverede. Samtidig indikerer analysen, at gymnasieelever, som oplever lærere og kammerater som tilgængelige ressourcepersoner, der kan hjælpe fagligt, forventes at være mindre fagligt motiverede, men at en stigende positiv oplevelse af tilgængelige ressourcepersoner øger den faglige motivation. Som man kan forvente er der en positiv korrelation mellem gymnasieelevernes oplevede udbytte af virtuelle undervisningsaktiviteter og faglig motivation

\section{Kvalitative perspektiver}

Den kvalitative analyse resulterer i en række temaer, som alle nuancerer og/eller kan være med til at forklare det ovenfor tegnede billede. Temaerne identificeres som 'distraktion', 'sociale rammer', 'præstationspres', 'adgang til hjælp og sparring', 'manglende variation', 'fagvariation' og 'fordele og ulemper'. Først og fremmest er det klart, at mange har oplevet den virtuelle undervisning som sværere end almindelig undervisning, også selvom organiseringen måske ikke har været så meget anderledes end en almindelig skoledag. En af eleverne taler om, at "Det har været meget normalt, synes jeg. Unormalt, men samtidig meget normalt". At undervisningen har været sværere, skyldes ifølge flere af eleverne, at det er svært at holde motivationen, jf. fx dette citat: "så motivationen går væk, sådan når man bare ser sådan åh nej og man skal bare sidde og glo ind i skærmen i tre timer". En af de forklaringer herpå, der træder tydeligt frem i det kvalitative materiale, er det, vi har kaldet 'distraktion', forstået som det, at eleverne trækkes mod andre aktiviteter og dermed trækkes væk (eller dis-traheres) fra undervisningsaktiviteten (Aagaard 2015a, b). Hvor mange tidligere studier peger på, at eleverne trækkes mod det digitale og dermed 
distraheres fra det fysiske, er det i vores tilfælde omvendt. En af eleverne begrunder dette i, at der er så mange andre muligheder hjemme på værelset:

"Det er langt nemmere at miste fokus med virtuel undervisning, end det er ellers, for det er en helt anden følelse. Man sidder bare hjemme på sit eget værelse, og på den måde er det [undervisningen, red.] lidt kedeligt ift. alt andet man kan lave på sit værelse. (...) der er ikke så meget andet man kan lave i et klasselokale. Så, på den måde kan det godt virke kedeligere. Men, det har været god undervisning, synes jeg, men det har været sværere at holde fokus i timerne."

I lighed med tidligere studier, er det den faglige undervisning, eleven distraheres væk fra. Eleven indikerer, at skolen som fysisk ramme har stor betydning, fordi der ikke er andre fristelser, der kæmper om opmærksomheden.

En anden forklaring på den manglende motivation og oplevelse af mestring, som træder frem i vores kvalitative materiale, er de anderledes sociale rammer. En af eleverne taler fx om, at

"Altså, jeg synes den har været sværere end oppe på skolen, for oppe på skolen, der har man kunnet sidde og snakke sammen og fă hjælp af en hel masse, og der skulle man ikke nødvendigvis aflevere noget efter hvert modul, så jeg synes, der har været mere pres"

Også en anden elev peger på den manglende kontakt og mulighed for hjælp som en af de ting, der har været særligt udfordrende:

"Selv oplevede jeg ikke den følelse af, at man ikke præsterede til det ønskede, men jeg kan forestille mig, at fordi der ligesom har været minimal kontakt til lærerne ift. opgaverne, har de derfor været sværere at løse. (...) Man ikke kunne blive vejledt så meget så meget som man kunne til fysisk undervisning"

Hermed bekræftes tidligere undersøgelser, der peger på den sociale kontakt som afgørende for både trivsel og deltagelse i undervisningen (Johnson \& Johnson, 1989; Ladd, 2003, 2005). Metaanalysen præsenteret i Johnson \& Johnson (1989) viste, at elever, der oplever kontakt og samarbejde bruger betydeligt mere 'time on task', dvs. tid på det faglige arbejde, end hvis de ikke har denne oplevelse.

Kontakten og mulighed for hjælp er ifølge flere elever udfordret af overgangen til mere skriftbåren kommunikation:

"For det første er det vigtigt når man er i skole, at få at vide af læreren, hvad det er man skal. Man skal sættes ind i ting, og man kan ikke bare forklare det over tekst på Lectio $\mathrm{fx}^{\prime \prime}$.

Samtidig betyder den uvante situation, at eleverne selv har oplevet det lidt sværere at spørge efter hjælp: "Folk er vant til det der med, at man hele tiden kan spørger sin lærer eller spørger nogle af de andre, og det er lidt sværere, når man sidder virtuelt på en eller anden måde". Eller, som en anden elev taler om, blev der skabt en distance til underviseren, så man ikke altid fik spurgt om det, der var behov for at spørge om:

"Nok mange, der ligesom glemte at spørge ham [underviseren], for han ville nok godt svare på, hvordan man skulle komme i gang, det er slet ikke det, men måske fordi alle sad i det samme, på den måde som man nu sad på, så var der nok nogen, der ikke fik spurgt i hvert fald".

Andre forklarer det ikke med en manglende lyst til at sige noget i det virtuelle rum, men med det, at kommunikationen simpelthen bare fungerer dårligere: 


\begin{abstract}
"Altså jeg synes også personligt, at det var kommunikationen, der var sværest under perioden, fordi det var lidt svært når vi var så mange i sådan et enkelt zoom-møde, hvor folk lidt kom til at tale i munden på hinanden, og der var ligesom ikke de samme muligheder for læreren for at komme i dialog med den enkelte elev, der havde spørgsmål eksempelvis"
\end{abstract}

Eleven her peger på, at kommunikationen er udfordret af, at det er svært at organisere en dialog i det virtuelle rum. Dette kan skyldes forskellige forhold. Et genkommende tema i vores kvalitative data er de tekniske forhold, hvor flere også har oplevet udfordringer med internetforbindelsen:

"Det er jo ikke alle, der har super god internetforbindelse og kan trække, at der er 15 klassekammerater der har kamera på, plus at man har sit eget kamera på. Det trækker jo på internettet, og hvis du sidder i en lejlighed med kun 5 Mbit ned og 5Mbit op, så lagger det jo eller hakker"

I litteraturen er der studier, der peger på, at elevers deltagelse generelt set faldt under skolenedlukningerne, og at dette kan tilskrives elevers oplevelse af skift i både materielle, pædagogiske og relationelle faktorer, der forandrer sig når undervisningen pludselig foregår online (Bray, Banks, Devitt, \& Eilís Ní, 2021).

Et andet forhold, som fremhæves af flere elever er, at dynamikken forsvinder ved overgangen til virtuel undervisning, og at det udfordrer den kollektive læring, som finder sted ubemærket i den almindelige undervisning. Her fortæller en elev: "Savner det der i undervisningen med at kunne samarbejde med sine klassekammerater og lige få en snak med læreren; altså det er de der snakke, hvor man udvikler sig og lærer af hinanden, og det får man bare ikke".

Herudover oplever flere, at skiftet til virtuel undervisning også har været et skift til mere individuelt arbejde, hvilket også udfordrer kontakten og muligheden for hjælp; "Man laver lidt det der individuelle arbejde, så man får ikke den der sparring, man har været vant til". Et andet skift ifm. overgangen til virtuel undervisning, som påvirker muligheden for hjælp, er skiftet væk fra tavleundervisning. En af eleverne forklarer:

\footnotetext{
"Og så tror jeg også, det har jeg i hvert fald oplevet især i matematik i vores klasse, at folk er vant til, at vores lærer nogle gange har skrevet noget på tavlen, der hjælper en med ligesom at komme i gang. Det var ikke rigtigt muligt på samme måde, når vi har været virtuelt, og derfor var der også i vores klasse en generel stemning, især i matematik, at de kunne ikke rigtig komme i gang med det, de skulle lave, fordi den der hjælp på tavlen ikke var der"
}

Udfordringerne med tavle-undervisningen forklarer nogle eleverne med manglende lærerkompetencer. Fx taler en elev om, at "De er ikke så tekniske, så de måske kunne lave en tavle på computeren, og man kunne udlevere sådan en pen pad, sådan en hvor man skriver". Erfaringer fra andre lande viser også, at det er lærere der har tidligere erfaring med distance undervisning, som er mest engagerede i virtuel undervisning under covid-19 pandemien (Jelinska \& Paradowski, 2021).

En helt anden udfordring knyttet til den manglende kontakt, som også kan påvirke den faglige motivation, er ifølge en elev, at det er sværere at blive set; "Man skal mere 'kæmpe' om at komme i kontakt over zoom for at kunne vise sin faglige indsigt og sine faglige evner"

Variation i undervisningen var et tema i de kvantitative analyser og er det også i de kvalitative. En elev siger "Jamen der er jo ikke noget variation i opgaverne, når man får dem over en computerskærm". Andre taler om, at "Undervisningen har været meget mere præget af, at man skal aflevere ting" og "Det bliver meget ensformigt, altså arbejdsformen, man sidder her, hver for sig, skriver på docs og så løser en opgave". Der tegner sig i dataene et billede af, at oplevelsen af manglende variation ikke nødvendigvis skal forstås som udtryk for, at der ikke er skiftet mellem forskellige arbejdsformer, men simpelthen som en konsekvens af, at 
alle arbejdsformerne skulle omsættes til noget virtuelt, og alene den virtuelle grænseflade skabte en oplevelse af, at det var monotont. Mangel på kommunikation og interaktion under virtuel undervisning er også set i andre kontekster, hvor også de mange timer foran skærmen, følelsen af isolation fra andre og problemer med koncentrationen var stress-faktorer for elever (Giannoulas, Stampoltzis, Kounenou, \& Kalamatianos, 2021). Forskning peger på, at de lærere, der er mest engagerede i virtuel undervisningen er dem der underviser synkront, hvor der er mulighed for at diskutere indholdet (Jelinska \& Paradowski, 2021), og det er samtidig også tilgange til undervisningen, der promoverer kritisk tænkning og kreativitet, som elever reagerer bedst på, og hvor de føler sig mest engagerede i virtuel undervisning (Bray et al., 2021).

Udover at den virtuelle undervisning ifølge eleverne har været mere monoton og individualiseret, har den ifølge flere elever også været travl. En elev taler om, at "Der har ligesom været en misforståelse ift. hvad lærerne tror, vi kan nå".

Herudover fremhæves karakteren af de enkelte fag og vigtigheden af forskellige aktiviteter og typer af centrale opgaver inden for det enkelte fag som havende afgørende betydning for, hvordan den virtuelle undervisning har været oplevet. Det antydede vi allerede ovenfor med citaterne, der nævner religion og matematik, og generelt er forskellene mellem fag et centralt tema i det kvalitative materiale. En elev forklarer fx, at: "Jeg synes, det kommer lidt an på faget. Der er nogle fag, der har det fungeret bedre end andre" og "Det har lidt været forskel i forhold til, hvilke fag det har været, fordi i nogen har det fungeret rigtig fint, og det har kunnet lade sig gøre, men så har jeg fx drama...". Der er flere, der nævner de eksperimentelle fag som særligt udfordret, jf. fx:

"Jeg synes, det er lidt svært i kemi, fordi hvis der er noget, man har brug for hjælp til... og så kan man heller ikke rigtig lave forsøg og sådan noget. Man får bare smidt en masse opgaver i hovedet, og så skal man lave dem, og så er det lidt ærgerligt, hvis man ikke kan få hjælp"

Men det fag, der flest gange omtales, som vanskeliggiort af skiftet til den virtuelle undervisning, er matematik. En af eleverne taler om, at:

"der er lige matematik, [...] der har det måske været lidt kringlet, fordi hvis han skulle forklare en formel eller sådan et eller andet på tavlen, [...] det er bare mere kompliceret, end hvis vi sad ovre i skolen".

Som vist i det ovenstående er det mest udfordringer og begrænsninger, der træder frem i de kvalitative data, men det er jo også en meget uvant situation og et pludseligt skift, eleverne har været udsat for. Der er dog også to mere positive temaer i de kvalitative data. Det ene handler om fleksibilitet i hverdagen og muligheden for at lave skolearbejdet, når det passer ind i en individuel dagsrytme, hvor en af eleverne taler om, at "Jeg kan godt lide det der med, at vi selv må bestemme. Om vi laver det om aftenen, eller om morgenen. Det kan være lige meget, bare så længe de får det". Et andet positivt tema handler om koncentration, hvor flere elever ser ud til at have fået øjnene op for den ro og mulighed for fordybelse, som den virtuelle undervisning kan give:

"Jeg tror det kunne være godt, hvis man havde både noget online og noget fysisk undervisning; så har du også en pause, hvor du kan sidde for dig selv, hvis man kan sige det sådan. Der er dét, at det er jo ikke alle der har lyst til at være sammen med folk i fire moduler en hel dag omringet af mennesker, men at man også har lidt tid til at gå ind i sig selv og koncentrere sig om opgaven. Så fx sådan nogle skriveopgaver kunne man jo godt lave derhjemme". 


\section{Konklusion}

I artiklen har vi undersøgt gymnasieelevers oplevelse af faglig mestring og motivation i forbindelse med den virtuelle undervisning under COVID-19. Analysen har vist, at især den faglige motivation var lav, og at tilgængelighed af ressourcepersoner er statisk signifikant korreleret med både faglig mestring og motivation. Også oplevet udbytte af virtuelle undervisningsaktiviteter korrelerer med faglig motivation. De kvalitative data indikerer, at oplevelsen af variation udfordres af, at skærmen kan få varierede aktiviteter til at fremstå ensformige og monotone, selvom der faktisk er en række skift. Samtidig viser analyserne, at eleverne i forbindelse med den virtuelle undervisning savner muligheden for at sidde og snakke sammen. Dette gælder både ift. kontakten med andre elever og lærerne. I forhold til sidstnævnte peger vores analyser på, at den manglende dynamik og umiddelbarhed fra tilstedeværelsesundervisningen begrænser sparringen og muligheden for at stille spørgsmål i den virtuelle undervisning. I de kvalitative analyser udpeges også den virtuelle kommunikation eller dialog som udfordret, fordi der tales i munden på hinanden. Afslutningsvist skal behovet for visualisering af arbejdet nævnes. I analysen var det tavlen til visualisering af matematik, der blev nævnt, men det gælder sikkert også i andre fag, at det kan være en fordel at have et dynamisk visuelt udtryk for en opgave.

\section{Diskussion}

Som påpeget indledningsvist går mange års erfaring med og forskning i virtuel undervisning forud for denne tid, men vi finder alligevel, at situationen er interessant, i og med at det virtuelle eksperiment i denne periode udmærkede sig ved at have den fulde population af danske gymnasieelever og -lærere som deltagere og ved at spænde over en længere periode, end det ellers har været tilfældet. Dette betyder ikke, at der kan generaliseres til andre perioder med virtuel undervisning, men situationen er interessant som case og kan bringe temaer op til diskussion og pege på vigtige opmærksomhedspunkter for fremtidig handlen. Når vi i det følgende skaber fokus på temaer og mulige handlinger i forhold til virtuel undervisning i gymnasiet, er der således ikke tale om svar, som vi generelt mener vil kunne styrke den virtuelle undervisning, men blot om bud på temaer og handlinger, der kan være relevante at reflektere og diskutere i konkrete situationer.

Den oplevede faglige mestring var ifølge analyserne mellem middel og over middel for alle gymnasiale uddannelsestyper, men den var højest på STX og lavest på HF. For den faglige motivations vedkommende var den lav for alle gymnasiale uddannelsestyper, men lavest på HHX og højest på HTX. Som vi gjorde det klart i afsnittet "Faglig mestring og motivation", udpeges netop disse to aspekter som væsentlige opmærksomhedspunkter ved skiftet til virtuel undervisning, hvor det er almindeligt kendt, at de udfordres. Da vi ikke har en baseline fra før den virtuelle undervisning begyndte at sammenholde artiklens resultater med, kan vi ikke entydigt sige noget om forskellen mellem ikke-virtuel og virtuel undervisning, men under alle omstændigheder er det væsentligt at have det for øje. Ideen om livslang læring har dybe rødder i den nordiske uddannelsesmodel (Esping-Andersen, 1989; Gustavsson, 2002), og derfor er det bekymrende, hvis den oplevede faglige mestring og motivation er udfordret.

Ifølge artiklens analyser korrelerer den oplevede faglige mestring med tilgængeligheden af ressourcepersoner. Som angivet under analyserne af de kvalitative data er dette ikke et ukendt fænomen. Tidligere undersøgelser bekræfter dette forhold, og også at det gælder såvel tilgængeligheden af lærere som tilgængeligheden af og samarbejdet med klassekammerater. Et forslag til at styrke oplevelsen af tilgængelighed kan være, at man i den virtuelle undervisning sætter 5 min af i starten og slutningen af undervisning til mere social dialog. Dette vil også afhjælpe elevernes oplevelse af, at lærerne fylder mere ind $\mathrm{i}$ undervisningen end normalt, og at tiden derfor er presset. Et andet forslag kunne være at opdele eleverne i sparringsgrupper, så de får mulighed for noget af den peer-to-peer-vejledning, som de savner fra den fysiske undervisning. Et forslag til at styrke den fælles dialog på klassen og dermed oplevelsen af klassefællesskabet kunne være at bruge chat eller padlet som udgangspunkt for dialogen. Med et 
sådant udgangspunkt vil alle kunne bidrage med input til dialogen, uden at man taler oveni hinanden. Dette vil også afbøde den udfordring, som i analysen blev eksemplificeret med eleverne, der talte om en kamp for at kunne vise sin faglige indsigt og faglige evner.

I artiklen viser vi videre, at den faglige motivation korrelerer med elevernes oplevede udbytte af undervisningen. Hvis man ønsker at arbejde med elevernes oplevede udbytte, kan man gøre det ved at italesætte det intenderede udbytte, når man introducerer opgaver og/eller man kan sørge for løbende feedback, enten lærer-feedback eller peer-feedback, så man løbende gør eleverne opmærksomme på det faglige udbytte af undervisningen.

Den faglige motivation korrelerer yderligere med oplevet variation. I forhold hertil kan det måske være relevant at tænke i variation, der også involverer aktiviteter væk fra skærmen, fx ved at ved at være i dialog på telefon, høre en podcast eller høre en oplæsning af tekst, mens man går en tur, eller ved at læse materiale på papir, forberede gruppearbejde udenfor computeren el.lign. Samtidig pegede analyserne på, at det kan være en fordel at tænke kreativt, hvilket blev eksemplificeret i citatet med eleven, der foreslår brug af pen pad til at skabe noget dynamik i undervisningen. Samtidig kan det være en god ide at holde hyppige pauser og lave hyppige tjek-ind. Sidstnævnte kan hjælpe eleverne til at finde tilbage i undervisningen, når de eventuelt har været faldet ud. I øvrigt kan nogle af pauserne - selvom eleverne er udfordrede på den meget høje skærmtid - laves som sociale pauserum. Sidst, men ikke mindst, pegede analyserne i artiklen på, at der er store faglige variationer, et opmærksomhedspunkt som igen minder os om den manglende mulighed for at generalisere.

\section{Begrænsninger og forbehold}

Den kvantitative metode giver mulighed for at kigge på det generelle frem for det specifikke. Dette kan være en styrke, når vi som i denne artikel gerne vil beskrive generelle forhold, der kan have betydning for elever i den virtuelle undervisning under skolenedlukninger eller lignende situationer i fremtiden. Det skaber dog også en forskydning i forhold til den enkelte elev, da den individuelle oplevelse af forholdene mellem de behandlede generelle fænomener selvoplevet "faglig mestring" og "faglig motivation" kan opleves anderledes, end de her er fremstillet.

Udover dette, så er der bred metodisk enighed om, at det indenfor de sociale videnskaber er vanskeligt at drage kausale slutninger eller udpege årsags-virknings sammenhænge. Der er tale om korrelationer, hvor retningen ikke er entydig: er bedre selvoplevet faglig mestring årsagen til øget faglig motivation eller omvendt? Måske forudsætter de begge hinanden?

De nævnte forhold er nogle, som læsere af denne artikel bør være opmærksomme på. Når det er sagt, så kan artiklens resultater udpege empirisk funderede forhold, som er relevante opmærksomhedspunkter for det fremtidige arbejde med virtuel undervisning, faglig mestring og motivation i gymnasiet. Empirisk funderede resultater er alt andet lige et godt supplement til fornemmelser og normative holdninger. 


\section{Forfattere}

\section{Ane Qvortrup}

Professor og leder af Center for Gymnasieforskning

Institut for Kulturvidenskaber, Syddansk Universitet anq@sdu.dk

\section{Rune Hejli Lomholt}

Videnskabelig Assistent

Institut for Kulturvidenskaber, Syddansk Universitet lomholt@sdu.dk 


\section{Referencer}

Aagaard, J. (2015a). Drawn to Distraction: A Qualitative Study of Off-Task Use of Educational Technology. Computers \& Education, 87: 90-97.

Aagaard, J. (2015b). Media Multitasking, Attention, and Distraction: A Critical Discussion. Phenomenology and the Cognitive Sciences, 14(4): 885-896.

Al Fadda, H. (2019). The Relationship between Self-Regulations and Online Learning in an ESL Blended Learning Context. English Language Teaching, 12(6), 87-93. doi:10.5539/elt.v12n6p87

Ary, D.; Jacobs, L.C.; Razavieh, A.; Sorensen, C. (2009). Introduction to Research in education. Belmont, CA: Wadsworth Cengage Learning

Baldwin, S. A. (2019). Psychological Statistics and Psychometrics Using Stata. Texas: Stata Press.

Bandura, A. (1977). Self-efficacy: Toward a unifying theory of behavioral change. Psychological Review, 84(2), 191-215

Bandura, A. \& Wood, R. (1989). Effect of perceived controllability and performance standards on self-regulation of complex decision-making. Journal of Personality and Social Psychology, 56: 805-814

Berger-Tikochinski, T.; Zion, M, \& Spektor-Levy, O. (2016). Up and Down: Trends in Students' Perceptions about Learning in a 1:1 Laptop Model - A Longitudinal Study. Interdisciplinary Journal of e-Skills and Lifelong Learning 12: $169-191$

Berlingske (2021). Forskere og fagfolk i opråb: Vi står lige nu med en fagligt dummere årgang af gymnasie- og skoleelever. Lokaliseret 21/11-21 på: https://www.berlingske.dk/samfund/forskere-og-fagfolk-i-opraab-vi-staarlige-nu-med-en-fagligt-dummere

Bray, A., Banks, J., Devitt, A., \& Eilís Ní, C. (2021). Connection before content: using multiple perspectives to examine student engagement during Covid-19 school closures in Ireland. Irish Educational Studies, 40(2), 431-441. doi:http://dx.doi.org/10.1080/03323315.2021.1917444

Brooks, S. K., Webster, R. K., Smith, L. E., Woodland, L., Wessely, S., Greenberg, N. \& Rubin, G. J. (2020). The psychological impact of quarantine and how to reduce it: rapid review of the evidence. The Lancet, 395(10227), 912-920. doi:10.1016/ S2215- 0366(20)30077-8.

Chung, L.-Y. (2015). Exploring the Effectiveness of Self-Regulated Learning in Massive Open Online Courses on Non-Native English Speakers. International Journal of Distance Education Technologies, 13(3), 61-73. doi:10.4018/IJDET.2015070105

Cook, R. D. (1977). Detection of influential observation in linear regression. Technometrics, 19(1), 15-18.

Denzin, N.K. \& Lincoln, Y.S. (2000). Handbook of Qualitative Research. London: Sage Publications

Esping-Andersen, G. (1989) The three political economies of the welfare state. The Canadian Review of Sociology and Anthropology, 26: 10-36

Giannoulas, A., Stampoltzis, A., Kounenou, K., \& Kalamatianos, A. (2021). How Greek Students Experienced Online Education during COVID-19 Pandemic in Order to Adjust to a Post-Lockdown Period. Electronic Journal of e-Learning, 19(4), 222-232.

Gill, B.; Goyal, R.; Hartog, J.; Hotchkiss, J.; DeLisle, D. (2020). Considerations for Reopening Pennsylvania Schools. Regional Educational Laboratory Mid-Atlantic. Retrieved April 7, 2021 from https://www.muncysd.org/cms/lib/PAo6ooo076/Centricity/Domain/1/ReopeningPASchools.pdf 
Gulten, D. C.; Yaman, Y.; Deringol, Y. \& Ozsari, I. (2011). Investigating the Relationship between Curiosity Level and Computer Self Efficacy Beliefs of Elementary Teachers Candidates. Turkish Online Journal of Educational Technology -TOJET, 10(4), 248-254

Gustavsson, B. (2002). What do we mean by lifelong learning and knowledge? International Journal of Lifelong Education, 21: 13-23

Halkier, B. (2008). Fokusgrupper. Frederiksberg: Samfundslitteratur

Jelinska, M., \& Paradowski, M. B. (2021). Teachers' Engagement in and Coping with Emergency Remote Instruction during COVID-19-Induced School Closures: A Multinational Contextual Perspective. Online Learning, 25(1), 303-328.

Johnson, D. \& Johnson, R. (1989): Cooperation and Competition: Theory and Research. Edina, MN: Interaction

Ladd, G.W. (2003): Probing the adaptive significance of children's behavior and relationships in the school context: A child by environment perspective. In Kail, R. (red.): Advances in child behavior and development (vol. 31): 43-104. New York, NY: Wiley.

Ladd, G.W. (2005): Children's peer relations and social competence: A century of progress. New Haven, CT: Yale University Prenss

Larbi-Apau, J., Oti-Boadi, M. \& Tetteh, A. (2018). Computer Attitude and eLearning Self-Efficacy of Undergraduate Students: Validating Potential Acceptance and Use of Online Learning Systems in Ghana. International Journal on E-Learning, 17(2), 199-226.

Madonna, S., Jr. \& Philpot, V. D. (2013). Motivation and Learning Strategies, and Academic and Student Satisfaction in Predicting Self-Efficacy in College Seniors. Quarterly Review of Distance Education, 14(3), 163168

Mehmetoglu, M., \& Jakobsen, T. G. (2017). Applied statistics using Stata: a guide for the social sciences. London: Sage Publications.

Mutch, D. M. (2020). The Covid-19 Global Pandemic: A Natural Experiment in the Making. Lifestyle Genomics, $13(5), 135-137$.

Peck, L.; Stefaniak, J. E. \& Shah, S. J. (2018). The Correlation of Self-Regulation and Motivation with Retention and Attrition in Distance Education. Quarterly Review of Distance Education, 19(3), 1-15

Qvortrup, A. (2020a, red.). Gymnasiet i den historiske Corona-tid - et elevperspektiv. Hentet 30/11/21 fra: https://www.sdu.dk/-/media/files/om sdu/institutter/ikv/centre/cfs/rapport.pdf

Qvortrup, A. (2020b, red.). Gymnasiet i udvikling. København: Hans Reitzels Forlag

Qvortrup, A. (2021). Long-term consequences of COVID-19 on students' well-being and values. In Education in the North (in press)

Raykov, T. (1997). Estimation of composite reliability for congeneric measures. Applied Psychological Measurement, 21(2), 173-184.

Zhang, Y. \& Wildemuth, B.M. (2009). Qualitative analysis of content. In Windemuth, B.M. (ed.). Applications of social research methods to questions in information and library science. Westport, CN: Libraries Unlimited

Tladi, L. S. (2017). Perceived Ability and Success: Which Self-Efficacy Measures Matter? A Distance Learning Perspective. Open Learning, 32(3), 243-261

The Annie E. Casey Foundation (2020). KIDS COUNT Data Book, 2020: State Trends in Child Well-Being. Retrieved March 26, 2021 from https://www.aecf.org/resources/2020-kids-count-data-book/ 
Tosuncuoglu, I. (2019). The Interconnection of Motivation and Self Regulated Learning among University Level EFL Students. English Language Teaching, 12(4), 105-114

TV Midtvest (2021). Venstre-kvinde om corona-undervisning: - Vi taber nogle unge mennesker på gulvet. Lokaliseret 21/11-21 på: https://www.tvmidtvest.dk/coronavirus/venstre-kvinde-om-corona-undervisning-vitaber-nogle-unge-mennesker-paa-gulvet

Wang, Y.; Peng, H.; Huang, R.; Hou, Y. \& Wang, J. (2008). Characteristics of Distance Learners: Research on Relationships of Learning Motivation, Learning Strategy, Self-Efficacy, Attribution and Learning Result. Open Learning, 23(1), 17-28

Yang, Y.-C. \& Park, E. (2012). Applying Strategies of Self-Regulation and Self-Efficacy to the Design and Evaluation of Online Learning Programs. Journal of Educational Technology Systems, 40(3), 323-335 